\title{
On Making Monetary Policy More Effective Domestically and Internationally*
}

\begin{abstract}
ALLAN H. MELTZER
Increased interest in price stability as the principal goal of monetary policy raises an issue about how well central banks can meet that goal. One approach is to forecast inflation a year or more ahead. Inability to separate permanent inflation from transitory, one-time changes in price levels suggests that forecast errors cannot be held within the $2 \%$ range frequently used. The paper again suggests an adaptive rule for money growth. If adopted for the principal currencies, the proposed rule would increase welfare for participants. Countries that have the best records of inflation control have often followed a rule of this kind.
\end{abstract}

Key words: Price stability; Inflation; Monetary policy; Central banks; Credibility; Adaptive rules

The organizers of the Seventh International Conference have chosen a theme and a set of issues that, I believe, should be revisited frequently by all central banks. How can monetary policy be made most effective? What task or tasks should the central bank undertake in its role as protector of the value of money and all nominal obligations nationally and internationally? What institutional arrangements are most useful for fulfilling these responsibilities? How have recent developments in academic research and central banking practice changed our answers to these questions?

As is well-known, there is no single response to these questions that is applicable to all central banks and all time periods. Small and large countries have different opportunities. The opportunities are interdependent. At least since Keynes's $A$ Tract on Monetary Reform (1971), economists have known that a country's potential gain from the choice of monetary arrangements depends on the choices that other

"Revised version of a keynote address presented at the Seventh International Conference on "Toward More Effective Monetary Policy," sponsored by the Bank of Japan's Institute for Monetary and Economic Studies, October 26-27, 1995. This paper is to be included in the proceedings of the conference to be published from the Macmillan Press. The author thanks Bennett McCallum and Charles Plosser for helpful suggestions. 
countries make. Countries can only minimize the excess burden that arises from fluctuations in prices and exchange rates if this joint problem is solved.

One solution, that I have proposed at several earlier conferences, is for the leading monetary economies - the United States, Germany, and Japan - to adopt rules for price stability. By maintaining price stability, these countries would provide an opportunity for smaller countries to voluntarily fix their exchange rates and import zero inflation. The small economies would gain what they could not otherwise gain: both a fixed external value of money and zero or low inflation. Prices would fluctuate, but expected inflation would be zero. The large countries would gain also. They would each have expected inflation equal to zero. Their bilateral exchange rates would adjust to real disturbances, but monetary disturbances would be damped or absent. Further, large countries would benefit from trading at the fixed exchange rates maintained by smaller countries.

This proposal is rule-based and distinguishes between countries with different problems and opportunities. Large countries would have activist, rule-based policies to maintain zero expected inflation. Smaller countries could choose to follow a fixed exchange rate rule or could pursue an independent course if they chose to do so. I believe that a proposal of this kind would realize most of the potential welfare gains that monetary policy can provide, so monetary policy would be effective in raising welfare. I will return to this proposal in the concluding section, after discussing recent academic research on monetary policy and credibility, some relevant bits of monetary history, recent changes in practices at several central banks, and the possibility of achieving zero expected inflation.

Much recent academic research on monetary policy has sought to develop positive theories of monetary policy. Many of these theories are based on gametheoretic models that treat the policymaker as a constrained welfare maximizer concerned about credibility and aware of the relation between central bank credibility, independence, and the opportunities for reaching low or zero inflation. Within this framework, rules dominate discretion and adaptive rules typically dominate fixed rules. The dominance of rules over discretion follows from the assumption about information: The central banker and the public have access to information on the same terms and at the same cost. If this is not so, it is a fault of the central banker who always has the option of revealing information instead of exploiting it to surprise the public. The models recognize shocks, surprises or new information that was not available when the rule was formulated. An adaptive rule takes this information into 
account by adjusting the stimulus from policy action. Hence, it may be superior to a fixed rule. Whether it is superior in practice depends on the nature of the new information, particularly the persistence of changes, and on the rate at which the public adjusts or adapts. If all changes are transitory, there is no reason to adapt. An adaptive rule would have no advantage over a fixed rule.

Accompanying these developments in the theory of economic policy are some major changes in central banking practice. Three are of particular interest here. First, several central banks have announced that price stability is their primary or exclusive objective. Second, many central bankers recognize far more clearly than in the recent past that pursuit of a single objective - whether price stability or exchange rate stability - is more likely to be achieved if the central bank is independent of the political authority. Hence there is renewed interest in central bank independence, and several countries have adopted laws declaring the central bank "independent." Rule-based policies are another, possibly more effective, way to achieve central bank independence. Third, independence is seen as a step - perhaps a major step toward establishing credibility. Central bankers and market participants now recognize that lack of credibility reduces the value of central bank announcements and raises the cost of achieving central bank objectives. Indeed, in the absence of credibility, the cost of achieving policy objectives may make the objectives unattainable in practice.

The common concern of theorists and practitioners with price stability, independence and credibility may suggest more convergence of practice to theory than has, in fact, occurred. The activist central banker of the postwar years, who regarded the maintenance of the value of money as one of many objectives, and not the most important or overriding objective, is an historical aberration. Traditional central banks were private institutions to prevent governments from controlling money. They did not always succeed but those that followed gold standard rules were concerned first and foremost about the value of money. Central banks were wary of politicians interested in the use of monetary policy to give the appearance of prosperity, and on guard to prevent inflation or devaluation. Archetype central bankers of this century, like Britain's Montagu Norman or his American friend Benjamin Strong, were very aware of the risks of political pressure, though they did not always escape these pressures. They would not be surprised to learn that many of today's central bankers are struggling to establish or regain their independence so as to pursue as their main objective - the maintenance of the internal or external value 
of money.

Perhaps convergence has gone the other way - from central bankers' concerns to the positive theory of central banking. Here, too, there is reason for skepticism. The central banker - or policymaker - captured in current models is an unusual creature. Although central bankers traditionally have supported price or exchange rate stability in their public statements and private diaries, they have rarely achieved either. The current generation of positive theories has some difficulty explaining past or recent history. Although there are differences about why and where the failure occurred, there is now near unanimity that monetary failure caused the Great Depression. And, though positive theories of central banking can explain inflation, many have difficulty explaining rising inflation in the 1970 s and disinflation in the 1980s. The solution in most of these models is a positive steady rate of inflation, not rising inflation followed by disinflation. ${ }^{1}$

\section{Inflation Theory and Monetary History}

The 20th century has a rich monetary history, much of it at variance with positive models of central banking or monetary policy. The history includes the common experience of the Great Depression of the 1930s, the great inflation of the 1970s, and the disinflation of the 1980s, but it also includes some notable individual country experiences. In the interwar period, there was hyperinflation in Germany and Hungary and Britain's return to a gold parity at an overvalued exchange rate that required deflation in Britain and the countries that pegged their currencies to the pound sterling. In the post-Bretton Woods era, central banks in Argentina, Bolivia, Brazil, Chile, Israel and, most recently, Russia produced high inflation or hyperinflation for many years.

These experiences and many others raise a question: Why did central bankers or governments adopt the policies that produced these outcomes? My reading of history suggests not one but two answers. First, central bankers, policymakers and most others hold some core set of beliefs that they use to interpret events and decide on actions to be taken or avoided. Second, recognition of mistakes and revision in basic beliefs is often slow and costly.

With some exceptions, central bankers and government policymakers have been

${ }^{1}$ Some exceptions are Cukierman and Meltzer (1986) and Cukierman (1992). 
practical men who paid little attention to abstract ideas. Their beliefs are not cast as formal theories. Nevertheless theories function as guides to action and help to distinguish acceptable outcomes from those that require new initiatives.

At the beginning of the 20th century, two beliefs were firmly accepted by the practical men who managed central banks. The first was that the gold standard maintained long-run stability of both price levels and exchange rates. Neither the deflationary experience in the last quarter of the 19th century, nor the gradual inflation following the expansion of gold production late in that century, changed this belief.

The second belief was in the real bills or commercial loan theory of central banking. The proponents of this theory claimed that central bank discounts should be restricted to credits that arise in the financing of commerce and agriculture. If this were done, credit expansion would be limited and non-inflationary (see Mints, 1945).

Experience in Britain held that the discount rate at the Bank of England should remain between $2 \%$ and $10 \%$. During the deflation phase of the gold standard, when many countries joined the system, at the end of the 19th century, the Bank held to the $2 \%$ minimum rate for long periods, thereby requiring deflation as a solution for Britain and, given Britain's monetary role at the time, contributing to deflation in other gold standard countries. At the $2 \%$ discount rate, real costs of borrowing were high relative to profitability, so money growth remained deflationary. The deflationary phase was brought to an end not by a decision of central bankers to lower interest rates but by the expansion of gold production near the turn of the century (see Friedman and Schwartz, 1963a).

The Federal Reserve, founded just as World War I began in Europe, was too small and powerless to stop the inflow of gold in its early years. Moreover, under gold standard rules, it was not much inclined to act. Its initial policy was passive; it permitted inflation based on gold inflows. This was followed by a financing of wartime budget deficits, as in all of the belligerent countries.

Neither the prewar nor the wartime experience conforms to current positive theories of inflation. Nor is there evidence in the movements of interest rates that the inflation was expected to last. Nominal yields on long-term Treasury bonds remained below the rate of inflation.

The early postwar experience of all the belligerents was continued inflation followed by deflation, stabilization, and a return to a fixed exchange rate regime based on gold. Delays in reestablishing a fixed exchange rate tied to gold are attributable much more to factors such as the pressure to finance government borrowing, the size 
of prospective reparations, and demands for repayment of war debts than to any modern theory of the efficient rate of inflation (Chandler, 1958). Beliefs about gold were a more powerful force than any theory of optimal inflation. Only a few critics questioned the return to a type of gold standard in which gold was supplemented by foreign exchange reserves. This arrangement is called the gold exchange standard.

In the United States, the period from 1922 to 1929 is one of the few episodes in which the Federal Reserve delivered price stability and economic growth over a sustained period of five or more years. There were two mild recessions, followed in 1929-30 by another recession. That recession, as we know, became the Great Depression. Instead of delivering an optimal or efficient rate of inflation, most central bankers presided over a severe deflation. Reading the speeches, writings, and Federal Reserve minutes for the period suggests that mistaken beliefs were a main reason for the failure to act. ${ }^{2}$ What were those beliefs?

French officials did not like the gold exchange standard for many of the same reasons that they did not like the Bretton Woods system a generation later. Pride or caution encouraged them to hold only gold as a reserve, as in the United States and the United Kingdom, and prudence taught them that the gold exchange standard was vulnerable if several countries behaved as they did. Acting on these beliefs, they converted their foreign exchange balances into gold. The effect was to impose a deflationary impulse on falling world price levels (Eichengreen, 1992).

In the writings and discussions of Federal Reserve policy at the time, the word "inevitable" appears repeatedly. Deflation and depression were considered an inevitable consequence of the inflationary policies that had gone before. To a current observer, there are few signs of inflation in the late 1920s. To contemporary observers, however, the Federal Reserve had financed a stock market boom. Credit had been used for speculative purposes, not to finance real bills. Hence, the dominant belief of central bankers, bankers, and practical men was that the financial system had to undergo a correction. The correction could only end, they believed, when the demand for commercial loans encouraged banks to borrow by rediscounting real bills.

One notable exception is Sweden. Sweden, following Britain, left the gold standard in the fall of 1931 . Thereafter monetary policy, guided by three leading economists, aimed at price level stability. Their policy avoided much of the

\footnotetext{
${ }^{2}$ Meltzer (1994) develops this argument in greater detail.
} 
subsequent decline in output experienced elsewhere (Jonung, 1981).

There was no place for the current positive theory of optimizing social policy as long as belief in the gold standard or the real bills theory dominated central banks and many governments. Experience after World War II under the Bretton Woods system comes closest to the implications of the positive model. Although some policymakers in the Kennedy administration favored higher inflation as a means of increasing employment and achieving other social goals, I have found no evidence that the Federal Reserve under Chairman Martin accepted these arguments or acted on them. The inflation that occurred seems much more the result of two factors working together. The first is flawed operating procedures, particularly the use of free reserves as the principal indicator of the policy stance. Once operating errors produced inflation, the Federal Reserve was unwilling to pay the political cost of disinflating to maintain the exchange rate system. This is a point of contact with the positive theory of central banking. However, the positive theory does not explain why inflation increased from $1 \%$ to more than $10 \%$ a year between 1960 and 1980 . The second reason is that the Federal Reserve had an incomplete and partially formed theory of inflation. There were different ideas about what caused inflation; speculators, cost push, and government spending are examples commonly cited. The connection to monetary policy was not entirely clear to many Federal Reserve officials until much later.

Outside the United States, application of the positive theory is limited to countries that devalued repeatedly. France and the United Kingdom are in this group, but many countries were not. Some like Italy or Japan accepted the inflation coming from the United States. Germany and Holland revalued their currencies to avoid some of the imported inflation. No country maintained price stability. The main reason that countries other than the United States inflated, however, is their acceptance of the Bretton Woods rules.

The 1970s was a period of rising inflation and rising average unemployment in many countries. Monetary policymakers, freed of the constraints of Bretton Woods, responded in different ways to the oil shocks and other one-time commodity price increases. By the end of that decade, policymakers in many countries had given up any vestigial belief in their ability to manage a tradeoff between inflation and unemployment. Reducing inflation at acceptable social cost became a main policy goal in most developed countries.

Many of the European central banks repeated the mistake made by the British in 
the 1970s. They attempted to lower inflation by fixing the exchange rate, as Britain's Governor Norman had tried to do in 1925 (Chandler, 1958). The fixed exchange rate policy had a similar result in several countries - a persistently high unemployment rate. Until currency markets overwhelmed Italy, Britain, France, Spain, Portugal, and Sweden, governments and central banks in these countries continued to insist that a fixed exchange rate with Germany was the key to price stability or low inflation. I do not find much evidence for the socially optimizing central banker in these experiences.

Latin American countries are prominent among non-industrial countries that have recently declared their central banks to be independent. Here, too, there is not much support for the optimizing model of central bank behavior. Chile's inflation in the 1970s had such features as wage increases with prices controlled and rapid money growth to finance rising wages and transfer payments. Such policies seem better described as confiscation and transfer of wealth, based on beliefs or ideology, than as optimization of social welfare. Peru in the 1980s is similar to Chile in the 1970 s. In Brazil, there was repeated denial that inflation was caused by money growth and several efforts to stop inflation based on these beliefs. Argentina and Bolivia are other examples of countries with high inflation or hyperinflation that is better explained as the result of policies based on mistaken beliefs than as the outcome of optimizing behavior. Mexico's monetary problems in 1976, 1982, and 1994 occurred in election years. Socially optimal policies would not produce this pattern or its aftermath.

\section{Credibility}

The modern case for rules highlights the role of credibility. Analysis of credibility became an active research topic once Kydland and Prescott (1977) put a new foundation under earlier work on policy rules. Since that time, and particularly following Barro and Gordon's (1983) influential paper, there has been an explosion of literature on this topic. Much less has been done empirically. The brief survey of 20th-century monetary policy in the previous section finds little evidence that central banks generally behave as implied by positive models of the Barro-Gordon type. The stable inflation rate implied by these models is rare in practice. These models do not explain variable inflation, deflation or hyperinflation. Something is missing from these models that is present in practice. 
Informally, credibility is easily defined. It is a measure of the confidence that the public has that the central bank (or other policymaker) will follow the policy path to which it is committed. A more precise generic definition brings in the problem of time consistency (Kydland and Prescott, 1977). A policy is credible if, given his objectives, the policymaker maximizes by choosing the expected policy action when the time comes to act.

Some of the empirical problems are immediately apparent. Suppose the policy rule is inferred, not announced. How does the analyst or the public learn the policy rule other than by observation? With many possible contingent states, there will be uncertainty about how well a state contingent rule is known. The credible policy depends on the objectives of the policymaker, on the expectations of the public, on the public's knowledge of the rule. All of these are non-observables. Later work, for example, influential work on the reputation of the policymaker, does not narrow the number of non-observables. Further, these models assume away a major part of a central bank's problem - the control of the money supply. As some central bankers have noted, economists seeking to test the credibility of a rule-based policy cannot assume a close short-run relation between money and the price level (Issing, 1995; Rich, 1995).

The literature has two or three attempts to give quasi-operational definitions. For the case in which the policymaker announces targets, Cukierman and I (1986) defined average credibility as the extent to which the public expects the policymaker to deviate from the action consistent with the prior announcement. Marginal credibility is the response of the public's expectations to the announcement of a target. Notice that the expected rate of inflation can change continuously. Notice also that assuming a policy announcement gets rid of one problem but does not eliminate all non-observables - for example, expectations of the public and intentions of the policymaker.

Some additional, significant problems arise in testing credibility models. Most credibility modeling focuses on the policy rule for issuing money, the money supply, but does not model the supply. Moreover, money is used as a medium of exchange because it saves on information costs and transaction costs. These costs are not constant. Changes in intermediation and the growth of intermediaries are important for the rate of growth of the demand for money. Bordo and Jonung's (1987) empirical studies suggest that these changes in costs have brought large, permanent changes to the demand for money. Such changes are relevant for the choice of a 
policy rule. The policymakers' response to these changes must be part of any model that tests for credibility.

Further problems arise in empirical testing of credibility because there is uncertainty about the true model of the economy, and most policymakers do not announce rules. A policymaker finds it is in his interest to be ambiguous about the rule he follows (Cukierman and Meltzer, 1986). Simply put, the combination of neglect of inflation costs and intermediation, non-observables, ambiguity, and economists' inability to develop an empirically supported, dynamic model of the economy with low forecast errors makes empirical testing of credibility models an exceptionally challenging venture (see Weber, 1991).

Central bankers are adept at making ambiguous statements about their decisions and future actions. Ambiguity obscures the procedures they follow, the timing of policy actions, and the size of prospective changes. Ambiguity increases opportunities for discretionary action. Policymakers do not maximize credibilitywhatever that would mean. Many build credibility to use when they choose to surprise the public. Ambiguity contributes to surprises by keeping the public uncertain about the precise rule that is followed.

Evidence suggests that, in the absence of an announced, explicit rule, credibility is achieved only by performance. Three of the five countries with the lowest inflation since the Bretton Woods System formally ended in 1973 - Germany, Switzerland, and Japan - relied on a quasi-monetary rule during much of the period, and a fourth, the Netherlands, followed a fixed exchange rate rule by pegging its currency to Germany's. The fifth country, Singapore, followed what appears to an outsider to be an eclectic policy.

Each of the five countries had an average inflation rate of $4 \%$ or less for the period. The degree of formal independence differs. The Bank of Japan is nominally responsible to the Ministry of Finance, although practice varies. Cukierman (1992, p. 451) assigns it the same independence as the Federal Reserve. Yet Japan has had a lower inflation rate than the United States consistently. During much of the period, the Bank of Japan used a broad monetary aggregate to guide its policy. Difficulties began when this policy was replaced in 1985 by a policy of managing the exchange rate.

Germany and Switzerland are two of the most independent central banks. Each uses preannounced monetary targets to guide policy. Both banks have missed their targets several times. 
When explaining performance, theories of credibility do not add much to what one learns from the mean and variance of quarterly or annual inflation rates. People are right to believe that Japan, Switzerland and Germany have relatively credible monetary policies because they deliver lower rates of inflation than most other countries. Would we find their policies less credible if they delivered the same inflation rates but did a poorer job of hitting their announced or projected targets? Conversely, would we find them more credible if they hit their targets precisely but had a higher average rate of inflation. Our theories of inflation are not good enough to predict short-term changes in the rate of inflation accurately or to use our models to assign credibility rankings.

What seems important is that Germany and Switzerland promptly correct large errors. George Rich (1995) showed that there were three big misses in Swiss money growth after 1970 . Money growth of $60 \%$ in 1971 is followed by minus $20 \%$ in $1972 ; 35 \%$ in 1978 is followed by minus $25 \%$ in $1979 ; 20 \%$ in 1987 is followed by minus $10 \%$ in 1979 . I submit that these instances of decisive correction have more influence on the Swiss National Bank's credibility than either small annual departures or exact hits on a target. This should not suggest that targets are useless or that monetary targets are unnecessary. Switzerland would have experienced less variability and lower excess burden if monetary growth had been less variable. The three episodes show that Switzerland ignored its monetary target at times. They do not show that Switzerland gained from doing so.

Targeting money growth means the price level will be a random walk (or nearly so) whatever the expected rate of inflation. Suppose money growth is set to keep expected inflation at zero. A one-time price level change, distributed over time, can give rise to serially correlated, transitory, non-zero rates of price change. At times data will show prices rising or falling while the maintained rate of inflation is zero.

Suppose the central bank follows, but does not announce, a rule that keeps money growth equal to real output growth so that the unknown but true value of expected inflation is zero. There is no permanent inflation. There are transitory and permanent changes in the price level that make the rate of price change deviate from zero. For example, real shocks, changes in commodity taxes, or changes in intermediation may raise or lower the price level without changing the maintained or expected rate of inflation.

This is, of course, artificial. The public would eventually learn the rule. Nevertheless, it brings out a problem in measuring credibility that should not be 
ignored, particularly where the rule is opaque and changing. Discussion of inflation for the past 25 years has been plagued by the failure to distinguish temporary and permanent changes in the price level from permanent changes in the rate of inflation.

The Netherlands is an informative case. Here simple observation is clearly consistent with the definitions of credibility but not with most positive models of inflation. The Netherlands follows an easily observed rule. It pegs the guilder to the D-Mark and takes whatever inflation rate results. Since 1960, the Netherlands has revalued the guilder with every revaluation of the mark except one. One can treat the exchange rate as an announcement and observe what it is. We know the objective and we can use observation of the exchange rate to judge the credibility of the Netherlands central bank in carrying out its policy.

Or can we? Suppose the Netherlands does not follow Germany in the next revaluation of the mark. That experiment has been run. A one-time failure to revalue increased the interest rate differential between German and Dutch bonds. It took many years to remove the differential by restoring the policy of always revaluing with Germany. This suggests that market measures, such as the interest rate spread on comparable debt, may be useful as measures of credibility.

However it is measured, credibility is a stock that rises or falls with policy outcomes. Is the optimal degree of credibility the same as maximum credibility? Should a country build a stock and never use it so as to satisfy time consistency properties? Is it not more useful to analyze a political economy world where the policymaker is interested not only in the public interest but in his own interest and the two are not always the same. Even relatively independent central banks have been known to expand money growth in election years, as much research shows.

After Sweden, the United Kingdom, and Mexico each spent about $\$ 30$ billion or more to defend a fixed exchange rate, should they have borrowed more to maintain their credibility (assuming someone would lend)? Each of these countries was forced to devalue by from $20 \%$ to $60 \%$. Defending the parity cost about $\$ 700$ per capita in Sweden and more than $\$ 150$ in Mexico. Was Ricardo right when he told the Bank of England to deflate by $50 \%$ to reestablish the pound at the former gold parity? (He later changed his mind.) Economists generally agree with Keynes's ex post judgment that it was a mistake to restore the pound at its prewar parity in 1925.

After World War I, Montagu Norman and Benjamin Strong agreed that both the United States and the United Kingdom should deflate to restore prewar gold parities and price levels. Would it not have been socially better to use up some credibility 
and avoid the social costs of deflations in at least one country?

Consider recent experience in Latin America. After experience with inflation, devaluation and exchange rate problems in two previous election years, Mexico was able to establish sufficient credibility to return to world capital markets after 1989 by adopting institutional reform, and promoting privatization, budget balance, and other reforms. After decades of high inflation, default, devaluation, and workouts, Argentina reformed in 1990. In 1994 Brazil promised to reform for the sixth or seventh time in the past twenty years. Each of these countries received large loans and equity investments from presumptively rational investors abroad. Credibility appears to have increased despite long histories of trouble. This suggests a model in which large discrete changes in credibility can occur following reforms.

Argentina is a particularly interesting example of the use of institutionalization to increase credibility. In the past, I have been skeptical about the practical relevance of the literature on trigger strategies used to punish a policymaker who inflates (Barro and Gordon, 1983). These models eliminate a most difficult problem by assuming a representative individual who metes out the punishment. This abstracts from a highly relevant, possibly central, problem of coordinating individual actions to get a social response.

Argentina adopted a currency board but it added an important feature. The public can hold its deposits in dollars or pesos. Any risk of inflationary action can be followed by a shift into dollar deposits. This is an uncoordinated, but so far effective, punishment technique.

Until the EMS ran into difficulties in 1992-93, many papers discussed the role of the EMS in extending credibility from Germany to its neighbors. It is true that inflation rates fell in Europe, but the accompanying cost of unemployment was often higher in the EMS than in countries with flexible exchange rates. And unemployment rates fell more slowly in the EMS than outside - about 50\% slower in my comparison. Germany had one of the slowest rates of decline, although its maximum unemployment rate was lower than in most of the EMS and non-EMS countries.

Of course, factors other than credibility affect these observed differences. But Germany's credibility did not reduce costs for the EMS countries below those in the United States, the United Kingdom, Japan or Sweden. Each of the latter (non-EMS) countries experienced more rapid decline in unemployment rates than Belgium, Denmark, Germany, France, Ireland or Italy — members of the EMS. 
My conclusion is not that credibility is unimportant in practice. We do not know that one way or the other. Our models give either implications that lead to their easy rejection or implications that are not easily tested. At the subjective level, commitment by Britain to the EMS as a means of lowering the cost of inflation did not work as expected by its proponents. Nor has the EMS worked to lower social costs of disinflation in Spain, France, and Italy. Reported rates of inflation have fallen, but unemployment rates ranged from $12 \%$ to $24 \%$ several years after disinflation began. This is hardly a testament to the social benefits of commitment to the European Monetary System or the gain in credibility that such commitment achieves.

My conclusion is that game-theoretic literature teaches us some wrong lessons. Yes, ambiguity is important and so are credibility and the design of institutions. But recent game-theoretic literature fails as a positive theory of inflation. The Great Depression and the great inflation were not preplanned. There were mistakes. It was not a central banker or an obscure economist working in the bowels of the central bank that convinced much of the profession and many policymakers that the Phillips curve tradeoff could be used to get permanent or long-lasting increases in employment. It was Samuelson and Solow, leaders of our profession.

Much evidence suggests that the error has been recognized. Central banks are now trying to avoid their past mistakes. Inflation has fallen in the industrial countries. Positive theories of inflation based on optimizing behavior did not predict this.

\section{Inflation Targets}

Five countries - New Zealand, Canada, Britain, Sweden and Finland - have now adopted some type of inflation target as the sole or principal objective of monetary policy. The targets vary as do the time frames within which the target is to be achieved and the institutional arrangements under which the central bank operates. New Zealand has a formal contract that requires the central bank Governor to offer his resignation if the target is not achieved. In Finland and Sweden the inflation target is chosen by the central bank with, at most, a tacit understanding between the government and the central bank.

The common characteristics of these countries include the choice of an explicit target for inflation and a commitment to achieve the target within a few years (Leiderman and Svensson, 1995). Central banks in Germany, Japan, and Switzerland 
have followed low-inflation policies for a longer time, but they have expressed their targets in terms of some monetary aggregate. These countries choose the growth rate of the monetary aggregate to lower the inflation rate toward zero, but there is no commitment to a specific range for inflation or a time when inflation will be in that range. The United States is further removed from an inflation target. The current Chairman of the Federal Reserve often expresses his wish, or perhaps his personal intention, to reduce the inflation rate to a negligible value, but neither Congress nor the administration nor the Federal Reserve has endorsed the commitment, and there is no way of knowing whether the next Chairman would continue the commitment or wish to maintain it. Despite these differences, inflation has been reduced.

The choice of an explicit inflation target and a formal contract are, I believe, useful steps. In August 1988, I proposed a scheme to the Reserve Bank of New Zealand that differs modestly from the plan they later adopted. ${ }^{3}$ I suggested the use of a monetary aggregate as an intermediate target. The goal was to reduce inflation. The central bank would choose the target and conduct policy independently. However, the Governor would be required to offer his resignation if the target was not achieved. The Governor would be allowed to offer an explanation of any failure, and the government would have the option to accept the explanation instead of the Governor's resignation. The aim was to increase accountability by the political authorities, maintain the independence of the central bank over operations and choice of policy target, and increase the central bankers' incentives to achieve the targets they set.

The New Zealand contract improved on my proposal by binding the government and the central bank to the same goal. Elimination of the intermediate target may not be an improvement. It remains to be seen whether inflation targeting can maintain low inflation as well as monetary targeting has done in countries such as Germany, Japan (before 1986) and Switzerland. ${ }^{4}$

Central banks with inflation targets can, of course, choose a monetary aggregate as an indicator of inflation. None has announced its intention to do so. Some have developed feedback rules from interest rates or exchange rates to monetary instruments. I believe each has retained discretionary authority to change

\footnotetext{
${ }^{3}$ The proposal was based on a 1981 recommendation by the Shadow Open Market Committee but its antecedents lie in the 19 th century practice of finance ministers who resigned if they devalued the currency.

${ }^{4}$ Japan abandoned monetary targeting to control its exchange rate in 1986 and has had difficulty regaining economic stability since that time.
} 
implementation and procedures when and as they choose.

Restricting the goal or objective either by contract or announcement limits discretion. Central bankers are less free to shift objectives or to trade more inflation for temporary reductions in unemployment. They can, of course, announce their intention to let inflation rise temporarily, but such an announcement would eliminate the effect of surprise and, therefore, reduce or eliminate any desired response in employment or output.

Announcement of an inflation target moves in the direction of rule-like behavior. The extent of the move depends on how reliably central banks can achieve the targets and how serious they are about developing and explaining procedures to reduce the size and frequency of deviations from announced rates of inflation.

If economists could provide a validated, dynamic model of the inflation process that delivered accurate forecasts, achieving an inflation target with acceptable accuracy would be easier. Absent such models, several problems arise in the implementation of inflation targeting. Although there is some overlap, I will mention four problems: (1) the variability of lags between monetary impulse and its effect on inflation; (2) the problem of forecasting; (3) the problem of measurement; and (4) political interference.

Every policy rule or procedure depends for its successful implementation on a theory that relates the instruments that can be controlled to the objectives to be achieved. The instruments are open market operations, changes in the discount rate or some money market rate and the like. The objective of an inflation target is, of course, to keep inflation within a band that is sufficiently narrow to be both credible and acceptable to the public. Band widths of $2 \%$ are commonly used. Let me therefore take as a goal keeping inflation within a $2 \%$ band.

How much in advance must the central bank act to achieve that goal? Economists differ about the length of lags. Friedman and Schwartz (1963b) concluded that lags in the United States were long and variable. Real business cycle theorists claim the lags everywhere are constant at (or near) zero or would be if policy were fully credible.

Uncertainty about the average length of lags and the variability of lags poses a greater problem for a policy of judgmental adaptation or discretion than for a rulebased policy. The reason is that the length of the lag depends on structural parameters of the system. These parameters are not invariant to changes in operating procedures. Discretionary changes in procedure may accelerate or decelerate 
responses. Variability of lags adds to the uncertainty about whether the target will be achieved and puts pressure on the central bank to respond to dominant market interpretations or misinterpretations.

Successful discretionary policy requires relatively accurate forecasts of inflation and other variables. The record of central bank and private forecasting of inflation shows errors much larger than the bands used by central banks. Mean square errors of $60 \%$ to $100 \%$ of the average rate of inflation one quarter or one year ahead are common during the 1970s and 1980s (Meltzer, 1987). McNees (1995) reports root mean square errors for U.S. inflation one year ahead of $1.2 \%$ for the years 1980 to 1994 and $0.9 \%$ for 1983 to 1994 . This suggests that the width of a $95 \%$ confidence interval for the United States would be 4 to $5 \%$; a target of zero expected inflation would produce inflation rates between minus and plus $2-1 / 2 \%$.

Many forecasters use some type of Phillips curve relating inflation to the unemployment rate and other variables, including past inflation. A recent study by King, Stock and Watson (1995) found that this method produced root mean square forecast errors of approximately $1.6 \%$ for one-year ahead forecasts and $3.9 \%$ for twoyear ahead forecasts during the period 1954-94..$^{5}$ Moreover, the authors found considerable variance around the estimated value of the equilibrium level of unemployment, or NAIRU, at which inflation begins to rise. Their work suggests that a central bank that relies on the Phillips curve relation would be unlikely to remain consistently within a $2 \%$ band for inflation one or two years ahead.

Rasche (1995) reports similar results for several different sample periods. His lowest root mean square error is $1.1 \%$ for quarterly data from 1980 through 1993 . Rasche shows that most of the forecasting power from his Phillips relation comes from the lagged values of inflation. The unemployment rate contributes to the forecast, but its contribution is small.

A necessary condition for inflation is a sustained growth rate of money in excess of the growth rate of output. A considerable body of evidence for many different countries and time periods supports this proposition. A recent study by McCandless and Weber (1995) summarizes evidence from other recent studies and adds additional evidence for 110 countries. In the authors' words (McCandless and Weber, 1995, p. 4):

In the long-run, there is a high (almost unity) correlation between the rate of

\footnotetext{
${ }^{5}$ For the more stable years $1954-73$, the error is $1.1 \%$.
} 
growth of the money supply and the rate of inflation. This holds across three definitions of money and across the full sample of countries and two subsamples. ${ }^{6}$

Cecchetti (1995) computed correlations of seventeen different possible indicators of inflation with the U.S. inflation rate at leads of three months to three or four years. Using monthly data for 1967 to 1994 the highest correlation at a three-month or oneyear lead was the growth rate of $\mathrm{M}_{1}(0.72)$. The next highest correlations were for $\mathrm{M}_{2}$ at three months and the monetary base at one to two years, but these correlations were lower, 0.43 and 0.66 respectively. In a shorter monthly sample, 1982 to 1994 , the three highest correlations at a three-month lead are the rate of change of the nominal exchange rate, average hourly earnings and the monetary base. The last of these has a correlation of 0.8 for a three-month lead.

Contrary to the often repeated view that narrow monetary aggregates have little predictive power, Cecchetti's evidence suggests that growth of the monetary base has much more information about future U.S. inflation than most of the other sixteen variables he considered. At the two-year frequency, relevant for inflation targeting, growth of the monetary base is correlated to 0.66 in the full sample and 0.98 in the shorter sample. The federal funds rate is uncorrelated with inflation at all frequencies in the full sample and, at all but the one to two year frequency in the shorter sample. ${ }^{7}$ Further, Cecchetti reports that the root mean square error for one year ahead rolling forecasts of inflation using only the growth of the monetary base is $1.6 \%$ in the longer sample and $1.1 \%$ in the shorter sample, 1982-94. This compares favorably to Phillips curve estimates. Other commonly used measures such as the term structure spread or the spread between commercial paper and the Federal funds rate have zero or low correlations.

The monetary rule I have proposed requires the central bank to target the rate of growth of the monetary base, a variable over which it can exercise close control (Meltzer, 1987). ${ }^{8} \quad$ The rule is adaptive; the current growth rate of the monetary base adjusts to past rates of growth of velocity and real output.

I have arbitrarily chosen a four-quarter moving average of the growth rate of the

\footnotetext{
${ }^{6}$ See also Capie (1995) who summarizes the history of inflation and concludes that the only periods when inflation occurred were times when money expanded persistently.

${ }^{7}$ The correlation is 0.89 , however, in the $1982-94$ sample at the 1 to 2 year frequency.

${ }^{8}$ The complete statement of the rule also requires the central bank to post a penalty discount rate and provide the services of a lender of last resort.
} 
base as the variable to be controlled (or monitored) by the central bank and a twelvequarter moving average of the growth rates of base velocity and real output to guide changes in the growth rate of the base. As in equation (1), expected inflation $E(p)$ is zero when the four-quarter growth rate of the base, $b_{4}$, is equal to the twelvequarter growth rate of the difference between growth of output and base velocity, $y_{12}-V_{12}$.

$$
E(p)=0 \text { for } b_{4}=y_{12}-V_{12}
$$

By definition, $V=y+p-b$; substituting, we get that for $E(p)=0$

$$
b_{4}=b_{12}-p_{12}
$$

The expected rate of inflation for the next four quarters is

$$
E\left(p_{4}\right)=b_{4}-\left(b_{12}-p_{12}\right)
$$

Equation (1) is an identity if $b, y$ and $V$ have the same time dimension, and the same is true of equation (3). The right side of (3) describes the permanent or expected trend rate of inflation based on information currently available. It does not assure that all of the inflation will be realized in the next quarter. There are reasons for the differences. First, given the uncertainty about the length of lags and the arbitrary choice of the period over which to average $b$ and $b-p$, some of the expected inflation may have occurred; actual inflation can exceed or fall short of the trend rate shown on the right side of (3). As is well-known, inflation rates show considerable persistence. I use quarterly measured rates of inflation to adjust expected inflation for recent inflation. Second, as suggested by McCallum's version of a similar monetary rule (McCallum, 1988 and elsewhere), it may be useful to recognize that the inflation is affected systematically by fluctuations in output or employment such as occur during a business cycle. ${ }^{9}$ Third, changes in the terms of trade, excise taxes, oil shocks and other one-time price level changes introduce temporary changes in the rate of inflation. These changes will be left for the random term in a regression equation.

To introduce these changes in (3), let the four-quarter expected rate of inflation

\footnotetext{
${ }^{9} \mathrm{McC}$ allum uses the difference between current output and its trend growth. I use lagged unemployment to compare to a Phillips curve.
} 
equal next quarter's inflation rate plus actual inflation for the past three quarters plus an error term to allow for one-time changes in the price level.

$$
E\left(p_{4}\right)=E p_{t+1}-\left(p_{t}+p_{t-1}+p_{t-2}\right)
$$

where

$$
E\left(p_{t+1}\right)-p_{t+1}=\varepsilon_{t+1}
$$

Further, let $U_{t}$ allow for business cycle fluctuations in the measured rate of inflation.

With these changes, the rule becomes part of a regression equation to forecast inflation as shown in (6). The equation has the monetary rule, an autoregressive equation and a type of Phillips curve. The rule implies that the coefficients on $b_{4}$ and $\left(b_{12}-p_{12}\right)$ are equal. The statistical findings below do not reject this implication.

$$
p_{t}=a_{0}+a_{1} b_{4 t-1}+a_{2}\left(b_{12}-p_{12}\right)_{t-1}+a_{3} p_{t-1}+a_{4} p_{t-2}+a_{5} p_{t-3}+a_{6} U_{t-1}+\varepsilon_{t}
$$

Table 1 compares forecasting equations for the percentage rate of change of the GDP deflator using (separately) an autoregressive equation, a Phillips-type equation, and equation (6) with and without the lagged unemployment rate. All equations use quarterly data for the United States at annual rates for the period 1962:I to 1995:I.

Column 1 shows the autoregressive forecast. As is well-known, inflation persists, so the autoregressive equation captures much of the systematic variance in the measured inflation rate. Adding the lagged unemployment rate has a modest effect on the standard error of estimate (see). As Rasche (1995) suggests, the unemployment rate is statistically significant in the equation but contributes little explanatory power for the range of unemployment rates observed in postwar recessions. Column 3 uses the monetary rule with the lagged measured rates of inflation. Again, there is not much improvement over the autoregressive forecasts. Column 4, using equation (6), shows some improvement over the autoregressive equation. This version of the rule implies that, on average, a $1 \%$ change in the growth rate of the monetary base maintained for four quarters increases the quarterly rate of inflation by more than $0.3 \%$ at annual rates, other things equal. A three percentage point reduction in the growth rate of the base reduces inflation, directly, by one percentage point within a year and, indirectly, reduces inflation by nearly one percentage point more by changing the lagged inflation terms. Part of the reduction is, temporary, offset by any increase in unemployment or change in real base growth 
that results.

The last column of Table 1 reestimates the McCallum-type rule for the period 1980 to 1995 . Both the monetary and unemployment variables are much weaker than in the full sample, but the standard error of estimate is lower. Forecast errors for four recent quarters, however, are not uniformly lower using the equation for the shorter sample. The monetary and unemployment terms contribute to forecast accuracy. Forecast errors are generally larger in this period using the autoregressive equation. Table 2 shows these errors.

Table 1

Forecasts of Measured Inflation

(one-quarter inflation rate at annual rates)

\begin{tabular}{|c|c|c|c|c|c|}
\hline \multirow[t]{2}{*}{ Period } & \multicolumn{4}{|c|}{ 1962:I-1995:I } & \multirow{2}{*}{$\frac{1980: I-1995: I}{(5)}$} \\
\hline & (1) & (2) & (3) & (4) & \\
\hline \multirow[t]{2}{*}{$p_{-1}$} & 0.40 & 0.38 & 0.39 & 0.29 & 0.38 \\
\hline & $(4.85)$ & (4.41) & $(4.50)$ & (3.36) & $(2.89)$ \\
\hline \multirow[t]{2}{*}{$p_{-2}$} & 0.27 & 0.29 & 0.27 & 0.24 & 0.24 \\
\hline & $(3.05)$ & (3.29) & $(2.92)$ & $(2.72)$ & $(1.71)$ \\
\hline \multirow[t]{2}{*}{$p_{-3}$} & 0.23 & 0.25 & 0.20 & 0.25 & 0.28 \\
\hline & $(2.74)$ & $(2.89)$ & $(2.28)$ & $(2.96)$ & (1.99) \\
\hline \multirow[t]{2}{*}{$B_{-1}$} & & & 0.10 & 0.34 & 0.17 \\
\hline & & & (1.11) & $(3.22)$ & $(1.52)$ \\
\hline \multirow[t]{2}{*}{$(\bar{B}-\bar{p})_{-1}$} & & & -0.10 & -0.21 & -0.07 \\
\hline & & & $(0.33)$ & $(2.18)$ & $(0.47)$ \\
\hline \multirow[t]{2}{*}{$U_{-1}$} & & -0.18 & & -0.39 & -0.26 \\
\hline & & $(2.18)$ & & $(3.73)$ & $(1.42)$ \\
\hline see & 1.47 & 1.43 & 1.46 & 1.39 & 1.15 \\
\hline
\end{tabular}

Note: $t$-statistics (absolute value) in parentheses.

$p=$ quarterly measured inflation rate at annual rates (deflator).

$B=$ four-quarter growth rate of monetary base.

$(\bar{B}-\bar{p})=$ twelve-quarter moving average of real base growth.

$U$ =unemployment rate.

Subscripts denote lag length.

A by-product of Table 1 is the evidence showing that, on average, the standard error of measured inflation is large relative to the bands within which central banks seek to hold the inflation rate. One reason is that inflation, as measured, includes one-time price level changes from oil shocks, changes in commodity taxes, the terms 
of trade, weather and other non-monetary events. A monetary target abstracts from all or most of these changes; a price level or measured inflation target makes the central bank appear responsible for all such changes. In practice, central banks often exclude the most common types of one-time shocks by redefining the price level or rate of price change that they target. By excluding one-time price level changes, the central bank allows the price level to vary around the rate of inflation produced by monetary growth.

Table 2

Forecast Errors, U.S. Inflation

1994:II to $1995:$ I

\begin{tabular}{rcccc}
\hline \hline & Full sample (1962-95) & & \multicolumn{2}{c}{ Shorter sample (1980-95) } \\
\cline { 2 - 2 } \cline { 5 - 5 } & Rule & Rule & $\begin{array}{c}\text { Autoregressive } \\
\text { only }\end{array}$ \\
\hline 1994: II & 1.33 & & 1.65 & 1.87 \\
III & 0.23 & & 0.24 & 0.34 \\
IV & -0.66 & & -0.70 & -0.74 \\
1995: I & 0.29 & & 0.18 & 0.27 \\
\hline \hline
\end{tabular}

Although the rule contributes to forecast accuracy, the benefit of the rule lies less in its contribution to forecasts than its contribution to policymaking. The base can be controlled directly, so a central banker can use the base rule as a guide to policy action. If nominal and real base growth have remained on paths consistent with zero expected inflation, the policymaker should not react to changes in lagged rates of price change that temporarily raise or lower the current measured rate of price change. The difference between recent nominal and lagged real base growth gives information about the expected rate of inflation. For example, if increased intermediation reduces desired real money balances and raises monetary velocity, the gap between nominal and real base growth will widen. This implies that expected inflation will be higher, so the growth of the monetary base should be reduced to keep expected inflation at zero.

In the past I have suggested that the central bank should not choose either the price level or the measured rate of inflation as its target. The target $I$ have proposed is the expected rate of inflation. Using this target, the objective of the central bank is to prevent the public from making decisions based on anticipations of inflation. A monetary rule helps to make this important distinction clear to the public. Prices and 
measured inflation would not be constant, but changes in the rate of price change would be one-time events. Some of the public would interpret the changes as inflation or deflation. Since many of these changes are distributed over time, the ideal of no response would not be fully realized. Nevertheless, the proposal has an advantage that should not be neglected. The central bank would not be expected to roll back increases or decreases in the price level, so the public would avoid the real costs of these adjustments.

This description brings out a choice that governments and central banks must make in a world of zero (or low) inflation. Economic theory does not tell us whether it is better to keep the anticipated price level or the anticipated rate of inflation constant. One choice imposes costs of reversing price level changes; the other increases the variance of the long-run price level. One choice imposes costs of adjustment if there are lags, contracts or other impediments to price level adjustments; the other imposes long-term costs of uncertainty about the future price level. Research comparing or measuring these costs would be highly desirable.

\section{Conclusion: Rules and Discretion Again}

Much has happened both to practice and theory since Henry Simon proposed a rule for monetary policy or since Milton Friedman's Program for Monetary Stability (1959). Recently, several central banks seeking increased independence from their governments and more freedom to control inflation have tried to develop procedures that are understood by market participants and more predictable than in the past. Yet, in their public statements, they oppose rules. It may be useful to end by reconsidering the meaning of rules and discretion.

Friedman's lectures contain one of a very few efforts to define and measure discretion (1959, pp. 85-86 and 95-98). Most discussion of rules and discretion leaves entirely open what is meant by discretion.

Central banks do not behave haphazardly. Many try hard to behave in a consistent way so as to avoid misinterpretations. Governors and staff members speak and write frequently to inform market participants and the public about their procedures and their intentions. Market participants watch the same variables that central bankers watch, and they anticipate policy actions. In short, central bankers typically follow rules of behavior, but they do not like to make precise statements about the rules. They want to adjust rules flexibly and preserve the right to depart 
from the rule temporarily or change the rule permanently. There are many examples. The Federal Reserve has changed its target from free reserves to the federal funds rate, to some measure of reserve growth, and back to the federal funds rate. The Bank of Japan shifted in the mid-1980s from principal reliance on a broad measure of money growth to a policy of targeting the exchange rate. The Bundesbank has deviated from its announced monetary targets at times and has changed the monetary aggregate that it targets. The Swiss National Bank has intervened to manage the exchange rate by allowing the monetary base to exceed its announced growth rate. Most of these changes by the central banks were accompanied by announcements, speeches and papers that informed interested parties about some of the new procedures. I use the term discretion to refer to these changes in processes or procedures whether open or hidden in ambiguity. I know of no evidence that these changes have generally increased welfare. Some have clearly been costly.

Many central banks now express concern about the credibility of their policies for reducing and controlling inflation. Although major central banks continue to respond to rising unemployment rates, central bankers talk much less than in the past about a broad range of objectives and much more about the social cost of inflation and the social gain from price stability. It is difficult to conceive of credibility independently of a rule or rule-like behavior at least as to the objective of policy. It is difficult also to conceive of a credible policy of inflation control achieved by frequent changes in process or procedure. Frequent discretionary changes increase costs of information and raise doubts about the commitment to the central bank's announced objective.

I believe that central banks in the industrial countries no longer choose between rules and discretion as these terms were used in the past. The choices that many central banks now make are (1) the degree of ambiguity they maintain in announcing their rule, (2) the consistency with which they maintain procedures, and (3) the extent to which the rule covers both procedures and objectives, not just objectives. Evidence suggests that central banks that give most weight to the growth of monetary aggregates in the implementation of policy have had the lowest average rates of inflation and less variable inflation. Most models of central banking do not reach this conclusion. The models typically assume that the central bank can achieve its objective and they do not distinguish between maintained inflation and one-time price level changes.

The normative implications of available evidence are much less than fully 
general. As noted in the introduction, central banks cannot control both the internal and external values of money unless they act cooperatively. Economic theory does not give clear guidance about the relative merits of internal and external price stability, but it does suggest how countries can gain from cooperation.

I suggest three types of institutional arrangements to internalize the gain from cooperation. The United States, Germany and Japan should follow an adaptive monetary rule to achieve zero expected inflation. This would maintain the internal value of money in these countries, allow bilateral exchange rates to adjust to real shocks, and provide a public good for all other countries. Very small countries should eliminate the monetary operations of their central banks by establishing a currency board or a permanently fixed exchange rate and, to enforce their commitment, these countries should permit their citizens to use a non-inflating foreign currency as a medium of exchange or parallel currency. The central bank in a small economy can do much harm but has little prospect of improving on a fixed exchange rate, low-inflation solution. The remaining countries can choose between the advantages of a fixed exchange rate in a world of zero expected inflation or an independent monetary policy to prevent domestic inflation. Any other choice would fail to provide the benefits that countries can expect to gain from a stable world monetary order and more effective monetary policies. It is up to each country to decide whether it is small or medium-sized and whether it wishes to join the club of stability or undertake its own policy actions. Only the three largest countries should be restricted by a common commitment to a rule that maintains zero expected inflation and provides public benefits for them and for any country that accepts the requisite monetary discipline.

The proposal I have made is close to the practice of the Bundesbank (Issing, 1995), and fits well with the recent statement of Governor Matsushita of the Bank of Japan. Last spring Governor Matsushita wrote $(1995$, p. 6):

Firstly, each country should take appropriate policy responses to achieve the common objective of non-inflationary sustainable growth in accordance with domestic circumstances ... and, secondly, each country should make every effort to acquire the market's understanding of its firm policy stance, and thereby to eliminate uncertainties to as great a degree as possible.

A rules-based policy, with common rules in the largest countries, seems the most effective way to realize these objectives and, in the process, increase the contribution that central banks make to policy effectiveness and economic welfare domestically 
and internationally.

Allan H. Meltzer: University Professor of Political Economy and Public Policy, Carnegie Mellon University; Visiting Scholar, American Enterprise Institute, and Honorary Adviser, Institute for Monetary and Economic Studies, Bank of Japan

\section{References}

Barro, R. J. and D.B. Gordon, "A Positive Theory of Monetary Policy in a Natural Rate Model," Journal of Political Economy, 91, 1983, pp. 589-610.

Bordo, M. and L. Jonung, The Long-Run Behavior of the Velocity of Circulation: The International Evidence, New York: Cambridge University Press, 1987.

Capie, F., "Money and Prices in the Long Run," Economic Affairs, 15 (autumn), 1995, pp. 1520.

Cecchetti, S.G., "Inflation Indicators and Inflation Policy," NBER Working Paper 5161, June 1995.

Chandler, L.V., Benjamin Strong, Central Banker, Washington: Brookings Institution, 1958.

Cukierman, A., Central Bank Strategy, Credibility and Independence, Cambridge: MIT Press, 1992.

Cukierman, A. and A.H. Meltzer, "A Theory of Ambiguity, Credibility and Inflation under Discretion and Asymmetric Information," Econometrica, 54, 1986, pp. 1099-1128. Reprinted in A.H. Meltzer, A. Cukierman and S. Richard, eds., Political Economy, New York: Oxford University Press, 1991.

Eichengreen, B., Golden Fetters: The Gold Standard and the Great Depression, New York: Oxford University Press, 1992.

Friedman, M., A Program for Monetary Stability, New York: Fordham University Press, 1959.

Friedman, M., and A.J. Schwartz, A Monetary History of the United States, 1867-1960, Princeton: Princeton University Press for the National Bureau of Economic Research, 1963a.

- and - "Money and Business Cycles," The State of Monetary Economics, Review of Economics and Statistics, 45, suppl., February 1963b, pp. 32-64.

Issing, O., "Stability of Monetary Policy, Stability of the Monetary System: Experience with Monetary Targeting in Germany," prepared for the Symposium of the Swiss National Bank, Gerzensee, March 1995, Journal of Monetary Economics, (forthcoming).

Jonung, L., "The Depression in Sweden and the United States: A Comparison of Causes and Policies," in K. Brunner, ed., The Great Depression Revisited, Boston: Martinus Nijihoff, 1981. 
Keynes, J.M., A Tract on Monetary Reform, London: Macmillan and St. Martin's Press for the Royal Economic Society, 1971.

King, R.G., J.H. Stock, and M.W. Watson, "Temporal Instability in the UnemploymentInflation Relationship," Economic Perspectives, Federal Reserve Bank of Chicago, May/June 1955, pp. 2-12.

Kydland, F. and E.C. Prescott, "Rules Rather than Discretion: The Inconsistency of Optimal Plans," Journal of Political Economy, 85, June 1977, pp. 473-492.

Leiderman, L. and L. Svensson, "Inflation Targets: Introduction," in L. Leiderman and L.E.O. Svensson, eds., Inflation Targets, London: CEPR, 1995, (forthcoming).

Matsushita, Y., "Global Economic Integration and the Central Bank," Quarterly Bulletin, Bank of Japan, 1995.

McCallum, B., "Robustness Properties of a Rule for Monetary Policy," Carnegie-Rochester Conference Series on Public Policy, 29, Autumn 1988, pp. 173-204.

McCandless, G.T. Jr. and W.E. Weber, "Some Monetary Facts," Quarterly Review, Federal Reserve Bank of Minneapolis, Summer 1995, pp. 2-11.

McNees, S., "An Assessment of the 'Official' Economic Forecasts," New England Economic Review, Federal Reserve Bank of Boston, July/August 1995, pp. 13-23.

Meltzer, A.H., "Limits to Short-Run Stabilization Policy," Economic Inquiry, 25, January 1987, pp. 1-13.

- "Why Did Monetary Policy Fail in the Thirties?" unpublished manuscript, Carnegie Mellon University, 1994.

Mints, L.W., A History of Banking Theory, Chicago: University of Chicago Press, 1945.

Rasche, R.H., "How Useful and Reliable is the Unemployment Rate in Forecasting Inflation?" unpublished, Michigan State University, September 1995.

Rich, G., "Monetary Targets as a Policy Rule: Lessons from Swiss Experience," prepared for the Symposium of the Swiss National Bank, Gerzensee, March 1995, Journal of Monetary Economics, (forthcoming).

Weber, A., "Credibility, Reputation, and the European Monetary System," Economic Policy, 12, 1991, pp. 57-102. 